\title{
Factors Affecting Sleep Quality in High School Students and its Relationship with Nomophobia
}

\section{Lise Öğrencilerinde Uyku Kalitesi, Etkileyen Faktörler ve Nomofobi ile Illișkisi}

\author{
๑ Ayşe Gülsen Teker, ๑ Neşe Yakşi* \\ Marmara University Faculty of Medicine, Department of Public Health, Istanbul, Turkey \\ *Niğde Provincial Heath Directorate, Niğde, Turkey
}

\begin{abstract}
Objective: A good sleep quality is essential for biopsychosocial health Studies show that most high school students have poor sleep quality, and recently, nomophobia has also become common in high school students. This study aims to determine the factors affecting sleep quality and its relationship with nomophobia among high school students.

Materials and Methods: This cross-sectional study was conducted in 428 high school students. Pittsburgh sleep quality index and nomophobia scale were used for data collection. Factors affecting sleep quality were evaluated with both univariate and multivariate logistic regression analyses.

Results: The sleep quality in $65.7 \%$ of students was poor. Poor sleep quality was found to be increased by 1.70 (1.04-2.81) times in females; 6.82 (2.65-17.55) times in those having flu or other upper respiratory tract infections; $3.17(1.50-6.68)$ times in those with gastrointestinal disorders; 4.40 (1.48-13.10) times in those overweight; and 2.99 (1.36$6.57)$ times in those with severe nomophobia $(p<0.05)$.

Conclusion: Poor sleep quality in high school students is dramatic. Providing counselling on sleep hygiene, especially for risk groups and their families, will improve sleep quality among high school students. Keywords: Adolescent, student, sleep quality, nomophobia, Turkey
\end{abstract}

Öz

Amaç: Biyopsikososyal sağlık için iyi bir uyku kalitesi şarttır. Araştırmalar, lise öğrencilerinin çoğunun düşük uyku kalitesine sahip olduğunu göstermektedir. Son zamanlarda lise öğrencilerinde nomofobi varlığı da yaygındır. Bu çalışmanın amacı, lise öğrencilerinde uyku kalitesi düzeyini ve etkileyen faktörleri belirlemek ve uyku kalitesi ile nomofobi arasındaki ilişkiyi belirlemektir.

Gereç ve Yöntem: Kesitsel tipteki bu çalışma 428 lise öğrencisi ile yapılmıştır. Veri toplama için Pittsburgh uyku kalitesi indeksi ve nomofobi ölçeği uygulanmıştır. Uyku kalitesini etkileyen faktörler hem tek değişkenli analizlerle hem de çok değişkenli lojistik regresyon analizi ile değerlendirilmiştir.

Bulgular: Öğrencilerin \%65,7'sinin uyku kalitesi kötüdür. Kötü uyku kalitesi kadınlarda $1,70(1,04-2,81)$ kat; grip veya diğer üst solunum yolu enfeksiyonu geçirenlerde $6,82(2,65-17,55)$ kat; gastrointestinal rahatsızlığı olanlarda $3,17(1,50-6,68)$ kat; fazla kilolu olanlarda 4,40 $(1,48-13,10)$ kat; ağır nomofobi varlığında $2,99(1,36-6,57)$ kat daha fazladır $(p<0,05)$.

Sonuç: Lise öğrencilerinde kötü uyku kalitesi dramatik biçimde sıktır. Özellikle risk grupları ve aileleri için uyku hijyeni konusunda danışmanlık verilmesi lise öğrencilerinde uyku kalitesini artıracaktır.

Anahtar Kelimeler: Adölesan, öğrenci, uyku kalitesi, nomofobi, Türkiye

\section{Introduction}

Sleep is an absolutely necessary biological process for a healthy life. Sleep plays a critical role in brain function and body physiology including metabolism, appetite regulation and the functioning of the immune, hormonal and cardiovascular systems. Psychosocial health, school performance and risk-taking behaviors in adolescents are affected by sleep disturbances. The psychosocial health of adolescents with sleep disorders is negatively affected. Behavioral disorders, smoking, alcohol and substance usage, depression and anxiety problems are more common in the adolalescents with sleep disturbances. Even, interviews with families of adolescents who have attempted suicide have shown that these adolescents frequently experience sleep disorders. In addition, sleep disorders in adolescents result in high body mass index, high cholesterol level and high blood pressure (1). It is known that good quality sleep is inevitable for physical and mental health but studies in Turkey have shown that more than half of adolescents have poor sleep

Address for Correspondence/Yazışma Adresi: Assoc. Prof. Ayşe Gülsen Teker, Marmara University Faculty of Medicine, Department of Public Health, İstanbul, Turkey Phone: +90 5426046673 E-mail: aysegulsenteker@gmail.com ORCID-ID: orcid.org/0000-0003-4958-007X Received/Geliş Tarihi: 08.03.2021 Accepted/Kabul Tarihi: 01.04.2021

${ }^{\circ}$ Copyright 2021 by Turkish Sleep Medicine Society / Journal of Turkish Sleep Medicine published by Galenos Publishing House. 
quality. According to these studies, poor sleep quality is caused by factors such as age, sex, chronic illness, lack of physical activity and domestic violence (2-4). Additionally, the digital world also changes the sleep quality of adolescents. According to a study, internet addiction increases the risk of poor sleep quality more than twice (2). According to another study, there is a moderate positive correlation between smartphone addiction and daytime sleepiness (5). Nomophobia was first used by King et al. (6) as an abbreviation for "no mobile phone phobia" in 2010. It has been defined as discomfort and anxiety experienced when staying away from the mobile phone (6). Although it is not included in the Diagnostic and Statistical Manual of Mental Disorders (DSM), nomophobia has been defined and studied with different names by many researchers. In Turkey, nomophobia has been studied many times. These studies found moderate-severe nomophobia in more than half of the adolescents $(7,8)$. More than $90 \%$ of the adolescents in Turkey have their own mobile phones (9). And mobile phones are important parts of daily life of high school students. Therefore, it is important to determine the effect of mobile phones on the sleep quality of high school students.

The aim of this study is to determine the level of sleep quality and the affecting factors and to determine the relationship between sleep quality and nomophobia among high school students.

\section{Materials and Methods}

This cross-sectional study was conducted in a city center in Middle Anatolia named Niğde.

\section{Participants and Procedure}

Participants from 3 high schools in this province determined by cluster sampling method were included in the study. The sample size of the study was calculated using G*POWER software. When the power of the research is $95 \%$, the alpha value is $5 \%$ and the effect size is 0.3 ; the minimum sample size was determined as 220. All classes were included in the research by stratification according to their size. During the data collection period of the study, face-to-face education was suspended due to the Coronavirus disease-2019 (COVID-19) pandemic. For this reason, the data was collected via online questionnaires (Google forms) from the students through the school administration. If the student and their parents consent, the student filled out the questionnaire.

Niğde Ömer Halisdemir University Ethics Committee permission (protocol number: 2020/12-13 and date: 29/12/2020), institutional permission and informed consent of the participants and their parents were obtained.

\section{Measures}

In this study, socio-demografic form created after literature review by the researchers, Pittsburgh sleep quality index (PSQI) and Nomophobia scale were used.

PSQI: This scale was developed by Buysse et al. (10) adapted to Turkish by Agargun et al. (11). Cronbach alpha value was found to be 0.80 . PSQI is a 19-item self-report scale that evaluates sleep quality and disorder over the past month. It consists of 24 questions, 19 questions are self-report questions, 5 questions are questions to be answered by the spouse or roommate. The questions of the scale consist of 7 dimensions (subjective sleep quality, sleep latency, sleep duration, habitual sleep efficiency, sleep disturbance, use of sleeping drugs and daytime dysfunction). Each dimension is evaluated on a score of 0-3. The total score of the 7 components gives the total score of the scale. The total score ranges from 0-21. A total score greater than 5 indicates "poor sleep quality".

Nomophobia scale: The scale was developed by Yildirim and Correia (12) The Turkish validity and reliability study of the scale in the 9-18 age group was conducted by Ozdemir and Bektas (9) and the Cronbach alpha value was found to be 0.90 . The Nomophobia scale consists of four dimensions and 20 items. The scale has four sub-dimensions: "inability to access information" (4 items), "loss of connection" (5 items), "inability to communicate" (6 items), and "not feeling comfortable" (5 items). Seven-point Likert scoring was used for rating (1: strongly disagree to 7: strongly agree). Scoring is done as follows:

Scale score $=20$ : No nomophobia

$21 \leq$ scale score $<60$ : Mild nomophobia

$60 \leq$ scale score $<100$ : Moderate nomophobia

$100 \leq$ scale score $\leq 140$ : Severe nomophobia.

\section{Statistical Analysis}

The data accessed through the online survey (Google forms) was analyzed using the SPSS 24 package program. Descriptive data was presented with median, minimum value, maximum value, frequency and percentage values. Chi-square test and Fisher's Exact test were used in the analysis of categorical data; Student t-test and Mann-Withney $U$ were used in the analysis of continuous data. Also, logistic regression analysis with "enter" method was used for multivariant analysis of factors affecting sleep quality. The statistical significance level was accepted as 0.05 .

\section{Results}

This study was completed with the participation of 428 students; 130 students (30.4\%) from sports high school, 139 students (32.5\%) from science high school and 159 students (37.1\%) from health vocational high school in Niğde. Two hundred-ninety one $(68.0 \%)$ of the students were females and median age number was 16 (13-18). Socio-demographic characteristics are shown in detail in Table 1.

Three hundred-eighty one $(89.0 \%)$ of the participants have their own phone. Eleven students (2.6\%) have chronic diseases and 10 students (2.3\%) use a drug regularly. Asthma (2), heart disease (2), epilepsy (1), kidney disease (1), migraine (1), hypertension (1) and eye disease (1) have been specified as chronic disease. In addition, 5 students (1.2\%) stated that they have a previously diagnosed psychiatric disorder. Major depression (2), intermittent explosive disorder (2) and anxiety disorder (1) were the diagnosed psychiatric disorders. The 
number of participants who had flu or other upper respiratory tract infections in the last month was 72 (16.8\%). This number was 14 (3.3\%) for COVID-19 and 81 (18.9) for gastrointestinal disease. Approximately one out of every two female students stated that their menstrual periods were painful and difficult. The frequency of smoking was $2.8 \%$ and the frequency of alcohol usage was $1.9 \%$. It was observed that $44.2 \%$ of the students did not exercise regularly. One out of every 10 students included in the study was overweight or obese. Domestic physical violence frequency among the students was 3.3\%, while the domestic verbal violence frequency found te be $15.7 \%$. According to the total score of the nomophobia scale, $46.3 \%$ of the students were found to be moderately nomophobic and $16.1 \%$ were severely nomophobic (Table 2).

The median value of the PSQI score, which indicates the sleep quality of the participants, was found to be 6 . When the cut-off

\begin{tabular}{|c|c|c|}
\hline \multicolumn{2}{|l|}{$n=428$} & n (\%)* \\
\hline \multicolumn{2}{|l|}{ Age } & $16(13-19)$ \\
\hline \multirow{2}{*}{ Gender } & Female & $291(68.0)$ \\
\hline & Male & $137(32.0)$ \\
\hline \multirow{4}{*}{ Class } & 9 & $148(34.6)$ \\
\hline & 10 & $145(33.9)$ \\
\hline & 11 & $75(17.5)$ \\
\hline & 12 & $60(14.0)$ \\
\hline \multirow{3}{*}{ School type } & Sports high school & $130(30.4)$ \\
\hline & Science high school & $139(32.5)$ \\
\hline & Health high school & $159(37.1)$ \\
\hline \multirow{2}{*}{ Mother's alive } & Yes & $424(99.1)$ \\
\hline & No & $4(0.9)$ \\
\hline \multirow{6}{*}{$\begin{array}{l}\text { Mother's } \\
\text { education level }\end{array}$} & Illiterate & $22(5.1)$ \\
\hline & Literate & $6(1.4)$ \\
\hline & Primary school & $175(40.9)$ \\
\hline & Secondary school & $74(17.3)$ \\
\hline & High school & $75(17.5)$ \\
\hline & University and above & $76(17.8)$ \\
\hline \multirow{2}{*}{ Father's alive } & Yes & $413(96.5)$ \\
\hline & No & $15(3.5)$ \\
\hline \multirow{6}{*}{$\begin{array}{l}\text { Father's } \\
\text { educational } \\
\text { level }\end{array}$} & Illiterate & $5(1.2)$ \\
\hline & Literate & $3(0.7)$ \\
\hline & Primary school & $109(25.5)$ \\
\hline & Secondary school & $97(22.7)$ \\
\hline & High school & $99(23.1)$ \\
\hline & University and above & $115(26.9)$ \\
\hline \multirow{3}{*}{$\begin{array}{l}\text { Perceived } \\
\text { income level }\end{array}$} & Income is lower than expenses & $115(26.9)$ \\
\hline & Income is equal to expenses & $229(53.5)$ \\
\hline & Income is more than expenses & $84(19.6)$ \\
\hline \multicolumn{2}{|l|}{ Sibling number } & $3(1-8)$ \\
\hline
\end{tabular}

point is accepted as 5, it was found that $65.7 \%$ of the students had poor sleep quality (Table 3 ).

According to the univariate analyzes, female students compared to male students $(p=0.030)$; low percieved income compared to others $(p=0.046)$; those who had flu or other upper respiratory tract infections in the last month compared to those who did not $(p<0.001)$; those who had COVID-19 in the last month compared to those who did not $(p=0.041)$; those who had gastrointestinal disorder in the last month compared to those who did not $(p<0.001)$; smokers compared to non-smokers $(p=0.010)$; among female students, those who had a painful and difficult menstrual period compared to those who did

\begin{tabular}{|l|l|}
\hline \multicolumn{2}{|l|}{$\begin{array}{l}\text { Table } 2 \text {. The characteristics of participants that may be associated } \\
\text { with sleep quality }\end{array}$} \\
\hline $\mathbf{n}=\mathbf{4 2 8}$ & $\mathbf{n}(\%)$ \\
\hline Having his/her own mobile phone & $381(89.0)$ \\
\hline Having a chronic disease & $11(2.6)$ \\
\hline Using a drug regularly & $10(2.3)$ \\
\hline Having a diagnosed psychiatric disorder & $5(1.2)$ \\
\hline $\begin{array}{l}\text { Having had flu or similar upper respiratory } \\
\text { tract infections in the last month }\end{array}$ & $72(16.8)$ \\
\hline Having had COVID-19 in the last month & $14(3.3)$ \\
\hline $\begin{array}{l}\text { Having a gastrointestinal disorder in the last } \\
\text { month }\end{array}$ & $81(18.9)$ \\
\hline Using medicine for sleeping & $3(0.7)$ \\
\hline $\begin{array}{l}\text { Painful and difficult menstrual periods } \\
\text { (n=288) }\end{array}$ & $151(52.4)$ \\
\hline Having own room & $275(64.3)$ \\
\hline Percieved school success as medium/bad & $253(59.1) / 11(2.6)$ \\
\hline Smoking & $12(2.8)$ \\
\hline Alcohol use & $8(1.9)$ \\
\hline Physical exercise & $239(55.8)$ \\
\hline Number of days exercised in a week (n=239) & $3(0.5-7)^{*}$ \\
\hline Being overweight/obese & $33(7.7) / 9(2.1)$ \\
\hline Tea/coffee consumption & $396(92.5)$ \\
\hline $\begin{array}{l}\text { Number of coffee/tea cups consumed daily } \\
\text { (n=396) }\end{array}$ & $2.5(0.5-20.0)^{*}$ \\
\hline Domestic verbal violence & $67(15.7)$ \\
\hline Domestic physical violence & $14(3.3)$ \\
\hline Moderate nomophobia/severe nomophobia & $198(46.3) / 69(16.1)$ \\
\hline $\begin{array}{l}\text { *Continuous variables are shown as median (minimum-maximum), COVID-19: } \\
\text { Coronavirus disease-2019 }\end{array}$ \\
\hline
\end{tabular}

Table 3. PSQI score and sleep quality classification of the participants

\begin{tabular}{|c|c|c|}
\hline & Median (minimum-maximum) \\
\hline \multicolumn{2}{|l|}{ PSQI score } & $6(0-14)$ \\
\hline & & n (\%) \\
\hline \multirow{2}{*}{ Sleep quality } & Good & $147(34.3)$ \\
\hline & Poor & $281(65.7)$ \\
\hline
\end{tabular}


not $(p=0.006)$; overweight and normal weighted individuals compared to underweight $(p=0.025)$; those who exposed to domestic verbal violence compared to who did not $(p=0.002)$ and those who were severely and moderate nomophobic $(p<0.001)$ compared to those who were not nomophobic or mildly nomophobic were found to have more frequent poor sleep quality (Table 4).

Age, parents living and education level, number of siblings, school type and class, presence of chronic disease, regular drug use, having diagnosed psychiatric disorder, perceived school success, having own room, tea and coffee consumption, alcohol use, physical exercise, domestic physical violence were found to have no statistically significant relationship with sleep quality according to univariate analyses ( $p>0.05)$.

According to the results of multivariate logistic regression analyzes; having poor sleep quality was found to be increased 1.70 (1.04-2.81) times among female sex compared to male sex; 6.82 (2.65-17.55) times among those who have had flu or other upper respiratory tract infections in the last month compared to did not; 3.17 (1.50-6.68) times among those who had gastrointestinal disorder in the last month compared to did not; 4.40 (1.48-13.10) times among the overweight students compared to underweight; 1.84 (1.14-2.96) times among the normal weighted students compared to underweight; 2.99 (1.36-6.57) times among severely nomofobics compared to non-nomofobics or mildly nomophobic $(p<0.05)$ (Table 5).

\begin{tabular}{|c|c|c|c|c|}
\hline$n=428$ & & $\begin{array}{l}\text { Good sleep quality } \\
(\mathrm{n} / \%)\end{array}$ & $\begin{array}{l}\text { Poor sleep quality } \\
(\mathrm{n} / \%)\end{array}$ & $p^{*}$ \\
\hline \multirow{2}{*}{ Sex } & Female & $90(30.9)$ & $201(69.1)$ & \multirow{2}{*}{0.030} \\
\hline & Male & $57(41.6)$ & $80(58.4)$ & \\
\hline \multirow{3}{*}{ Perceived income level } & Income is lower than expenses & $30(26.1)$ & $85(73.9)$ & \multirow{3}{*}{0.046} \\
\hline & Income is equal to expenses & $90(39.3)$ & $139(60.7)$ & \\
\hline & Income is higher than expenses & $27(32.1)$ & $57(67.9)$ & \\
\hline \multirow{2}{*}{ Using a drug regularly } & Yes & $1(10.0)$ & $9(90.0)$ & \multirow{2}{*}{$0.175^{* *}$} \\
\hline & No & $146(34.9)$ & $272(65.1)$ & \\
\hline \multirow{2}{*}{ Having a diagnosed psychiatric disorder } & Yes & $0(0.0)$ & $5(100.0)$ & \multirow{2}{*}{$0.170^{* *}$} \\
\hline & No & $147(34.8)$ & $276(65.2)$ & \\
\hline \multirow{2}{*}{$\begin{array}{l}\text { Having flu or upper respiratory tract } \\
\text { infection in the last month }\end{array}$} & Yes & $6(8.3)$ & $66(91.7)$ & \multirow{2}{*}{$<0.001$} \\
\hline & No & $141(39.6)$ & $215(60.4)$ & \\
\hline \multirow{2}{*}{ Having COVID-19 in the last month } & Yes & $1(7.1)$ & $13(92.9)$ & \multirow{2}{*}{$0.041 * *$} \\
\hline & No & $146(35.3)$ & $268(64.7)$ & \\
\hline \multirow{2}{*}{$\begin{array}{l}\text { Having a gastrointestinal disorder in the } \\
\text { last month }\end{array}$} & Yes & $11(13.6)$ & $70(86.4)$ & \multirow{2}{*}{$<0.001$} \\
\hline & No & $136(39.2)$ & $211(60.8)$ & \\
\hline \multirow{2}{*}{$\begin{array}{l}\text { Painful and difficult menstrual periods } \\
(\mathrm{n}=\mathbf{2 8 8})\end{array}$} & Yes & $36(23.8)$ & $115(76.2)$ & \multirow{2}{*}{0.006} \\
\hline & No & $53(38.7)$ & $84(61.3)$ & \\
\hline \multirow{3}{*}{ Percieved school success } & Poor & $1(9.1)$ & $10(90.9)$ & \multirow{3}{*}{0.127} \\
\hline & Moderate & $84(33.2)$ & $169(66.8)$ & \\
\hline & Good & $62(37.8)$ & $102(62.2)$ & \\
\hline \multirow{2}{*}{ Smoking } & Yes & $0(0.0)$ & $12(100.0)$ & \multirow{2}{*}{$0.010^{* *}$} \\
\hline & No & $147(35.3)$ & $269(64.7)$ & \\
\hline \multirow{4}{*}{ BMI classification } & Underweight & $73(40.3)$ & $108(59.7)$ & \multirow{4}{*}{0.025} \\
\hline & Normal & $64(31.7)$ & $138(68.3)$ & \\
\hline & Overweight & $5(15.2)$ & $28(84.8)$ & \\
\hline & Obese & $4(44.4)$ & $5(55.6)$ & \\
\hline \multirow{2}{*}{ Tea/coffee consumption } & Yes & $132(33.3)$ & $264(66.7)$ & \multirow{2}{*}{0.121} \\
\hline & No & $15(46.9)$ & $17(53.1)$ & \\
\hline \multirow{2}{*}{ Domestic verbal violance } & Yes & $12(17.9)$ & $55(82.1)$ & \multirow{2}{*}{0.002} \\
\hline & No & $135(37.4)$ & $226(62.6)$ & \\
\hline \multirow{3}{*}{ Nomofobia } & No/mild & $70(43.5)$ & $91(56.5)$ & \multirow{3}{*}{$<0.001$} \\
\hline & Moderate & $66(33.3)$ & $132(66.7)$ & \\
\hline & Severe & $11(15.9)$ & $58(84.1)$ & \\
\hline
\end{tabular}




\begin{tabular}{|c|c|c|c|c|}
\hline & & OR & $95 \% \mathrm{Cl}$ & $\mathbf{p}^{*}$ \\
\hline \multicolumn{2}{|l|}{ Female sex } & 1.70 & $1.04-2.81$ & 0.036 \\
\hline \multicolumn{2}{|c|}{ Having flu or upper respiratory tract infection in the last month } & 6.82 & $2.65-17.55$ & $<0.001$ \\
\hline \multicolumn{2}{|c|}{ Having a gastrointestinal disorder in the last month } & 3.17 & $1.50-6.68$ & 0.002 \\
\hline \multirow{4}{*}{ BMI classification } & Underweight & 1 & - & - \\
\hline & Normal & 1.84 & $1.14-2.96$ & 0.012 \\
\hline & Overweight & 4.40 & $1.48-13.10$ & 0.008 \\
\hline & Obese & 0.34 & $0.05-2.19$ & 0.262 \\
\hline \multirow{3}{*}{ Nomofobia } & No/mild & 1 & - & - \\
\hline & Moderate & 1.22 & $0.74-2.00$ & 0.417 \\
\hline & Severe & 2.99 & $1.36-6.57$ & 0.006 \\
\hline \multicolumn{5}{|c|}{$\begin{array}{l}\text { *Binary logistic regression-enter method (age, sex, perceived family income, using a drug regularly, diagnosed psychiatric disorder, flu or upper respiratory tract } \\
\text { infection in the last month, COVID-19 in the last month, gastrointestinal disorder in the last month, perceived school success, smoking, tea/coffee consumption, BMI } \\
\text { classification, domestic verbal violence, nomophobia variables were included in the model), BMI: Body mass index, COVID-19: Coronavirus disease-2019, Cl: Confidence } \\
\text { interval, OR: Odds ratio }\end{array}$} \\
\hline
\end{tabular}

\section{Discussion}

As a result of this research, it was observed that a significant part of high school students (65.7\%) had poor sleep quality. In previous studies conducted with high school students, it was found that more than half of the participants $(54.7 \%$ and $58.6 \%)$ had poor sleep quality $(2,3)$. The fact that poor sleep quality is so frequent shows that the importance of this issue is gradually increasing. Due to this study was conducted during the pandemic period, poor sleep quality may have increased. The negative mood caused by the pandemic and disturbed sleep hygiene as a result of changing daily routines may lead to an increase in sleep problems among students during COVID19 pandemic.

According to the results of this study, female students have increased risk compared to male students in terms of having poor sleep quality. A previous study showed that poor sleep quality risk increased 2.31 times among female high school students (4). Different biological characteristics and gender roles may put women at risk in terms of sleep quality as well as some other mental health problems.

This research found a strong relationship between having flu or other upper respiratory tract infections and poor sleep quality. It is clear that having a respiratory infection can acutely impair sleep quality. Previous studies have shown the association of poor sleep quality and infectious diseases (13). However, the relationship between sleep and infections is more complex and bi-directional. Poor sleep quality weakens the immune system and makes people more susceptible to many infections (14). Especially detoriation of immune system due to disturbed sleep quality among the students having frequent upper respiratory tract infections may turn the process into a vicious circle.

This research reveals that gastrointestinal problems are associated with poor sleep quality. A previous study showed that high school students with gastrointestinal problems are 2.68 times more at risk in terms of poor sleep quality (4). When these problems, which are not given enough importance in daily life, are not solved and become chronic, they negatively affect the quality of life and sleep.

This research revealed that especially overweight students are at risk in terms of poor sleep quality. Previous studies have revealed similar results (15). Being overweight and obese brings along poor sleep quality such as many other health problems. Another dramatic finding of this study is that $62.4 \%$ of the participants had moderate or severe nomophobia. In previous studies, it was determined that nomophobia was very common in high school students and it was detected in more than half of the students even up to $80 \%$ (16). Similarly, curfews due to COVID-19 pandemic and online education may have increased the nomophobia. In present study, it was observed that poor sleep quality increased 3 times with severe nomophobia. In a previous study including the high school students, it was shown that the poor sleep quality was associated with internet addiction (2). The results of this study seem to be concordant with literature, considering that young people's internet use is mostly via mobile phones. Intervention efforts to reduce nomophobia will also contribute to improving sleep quality. For this purpose, installing the applications that focus on reducing the screen time on smart mobile phones may be useful (17). Also cognitive behavioral therapies can be effective (18). Additionally, awareness raising activities about nomophobia and its negative effects on high school students are essantial.

\section{Conclusion}

The frequency of poor sleep quality among high school students is in a considerably dramatic level. Female sex, having had flu or other upper respiratory tract infections and gastrointestinal disorders, being overweight and having nomophobia have been shown to increase poor sleep quality. Determining and periodically monitoring the sleep quality of high school students, defining problems and developing solutions, providing counseling on sleep hygiene expecially for risk groups and their families will improve sleep quality among high school students. 


\section{Ethics}

Ethics Committee Approval: Niğde Ömer Halisdemir University Ethics Committee permission (protocol number: 2020/12-13 and date: 29/12/2020), institutional permission.

Informed Consent: Informed consent of the participants and their parents were obtained.

Peer-review: Externally and internally peer-reviewed.

\section{Authorship Contributions}

Concept: A.G.T., N.Y., Design: A.G.T., N.Y., Data Collection or Processing: A.G.T., N.Y., Analysis or Interpretation: A.G.T., N.Y., Literature Search: A.G.T., N.Y., Writing: A.G.T., N.Y.

Conflict of Interest: No conflict of interest was declared by the authors.

Financial Disclosure: The authors declared that this study received no financial support.

\section{References}

1. Medic G, Wille $M$, Hemels M. Short- and long-term health consequences of sleep disruption. Nat Sci Sleep 2017;9:151-61.

2. Kocas F, Sasmaz T. Internet addiction increases poor sleep quality among high school students. Turkish Journal of Public Health 2018;16:167-77.

3. Senol V, Soyuer F, Akca R, Argun M. The sleep quality in adolescents and the factors that affect it. Kocatepe Medical Journal 2012;14:93-102.

4. Tekcan P, Caliskan Z, Sarioz S. Sleep quality and related factors in turkish high school adolescents. J Pediatr Nurs 2020;55:120-5.

5. Sulun A, Gunay U, Sarman A, Dertli S. Daytime sleepiness in adolescents using smartphone. Journal of Dependence 2020;21:129-36.

6. King ALS, Valença AM, Nardi AE. Nomophobia: the mobile phone in panic disorder with agoraphobia: Reducing phobias or worsening of dependence? Cogn Behav Neurol 2010;23:52-4.
7. Cabi E, Alp D. A research on secondary school students' nomophobia levels. Karaelmas Journal of Educational Sciences 2020;8:149-59.

8. Eren B, Kilıc ZN, Gunal SE, Kircali MF, Oznacar BB, Topuzoglu A. Evaluation of nomophobia and related factorsi in high school students. Anatolian Journal of Psychiatry 2020;21:133-40.

9. Ozdemir EZ, Bektas M. Psychometric properties of a Turkish Version of the nomophobia scale for the Nine-Eighteen Age Group. J Pediatr Res 2020;7:316-22.

10. Buysse DJ, Reynolds CF, Monk TH. The Pittsburgh Sleep Quality Index: a new instrument for psychiatric practice and research. Psychiatry Res 1989;28:193-213.

11. Agargun MY, Kara $\mathrm{H}$, Anlar $\mathrm{O}$. The validity and reliability of the Pittsburgh Sleep Quality Index. Turk Psikiyatri Derg 1996;7:107-11.

12. Yildirim C, Correia AP. Exploring the dimensions of nomophobia: development and validation of a self-reported questionnaire. Comput Human Behav 2015;49:130-7.

13. Manian FA, Manian CJ. Sleep quality in adult hospitalized patients with infection: an observational study. Am J Med Sci 2015;349:56-60.

14. Ibarra-Coronado EG, Pantaleon-Martinez AM, Velazquez-Moctezuma J, Prospero-Garcia O, Mendez-Diaz M, Perez-Tapia M, Pav 'on L, Morales-Montor J. The bidirectional relationship between sleep and immunity against infections. J Immunol Res 2015;2015:678164.

15. Fatima Y, Doi S, Mamun A. Sleep quality and obesity in young subjects: a meta-analysis. Obes Rev 2016;17:1154-66.

16. Gurbuz IB, Ozkan G. What is your level of nomophobia? An investigation of prevalence and level of nomophobia among young people in Turkey. Community Ment Health J 2020;56:814-22.

17. Bychkov D, Young SD. Facing up to nomophobia: a systematic review of mobile phone apps that reduce Smartphone usage. In Big data in engineering applications. Springer, New York, 2018: 161-71.

18. Bekaroglu E, Yilmaz T. Nomophobia: differential diagnosis and treatment. Psikiyatride Guncel Yaklasimlar 2020;12:131-42. 